DOI: $10.24193 /$ tras.62E.9

Published First Online: 02/25/2021

\title{
TERRITORIAL INNOVATION PATTERNS IN ROMANIA. FUTURE PATHWAYS FOR SMART SPECIALIZATION ${ }^{\star}$
}

\author{
Cristina ȘERBĂNICĂ
}

\section{Cristina ȘERBĂNICĂ}

Associate professor,

Constantin Brâncoveanu University, Pitești, Romania

Tel.: 0040-755-031.755

E-mail: cpantelica@yahoo.co.uk

\section{Abstract}

This study examines the territorial patterns of innovation in Romania, a country labelled as 'modest innovator'. Our main assumption is that the large heterogeneity in the sub-national innovation patterns is not captured in the typologies developed for the NUTS2 regions. Consequently, the study proposes a categorization of the Romanian NUTS3 counties according to their innovation performance and structural characteristics, by means of a two-step factor analysis combined with hierarchical cluster analysis.

The results point to the existence of five territorial groupings with similar characteristics: knowledge-intensive hubs, technology-intensive platforms, diversified agglomerations, industrial production zones and structurally challenged regions. Taken together, the results suggest the need to prioritize structural transformation and embrace the broad-based innovation concept.

Keywords: innovation patterns, structural conditions, innovation policy, smart specialization, Romanian NUTS3.

* Acknowledgement: This work was supported by a grant of Ministry of Research and Innovation, CNCS - UEFISCDI, project number PN-III-P1-1.1-TE-2016-1630, within PNCDI III. 


\section{Introduction}

Since the early 1990s, a large body of literature has stressed the importance of regions as key drivers of innovation and the concept of regional innovation systems (RIS) has evolved into a widely used framework for innovation policy. Cooke, Gomez Uranga and Etxebarria (1997, p. 480) define regions as 'territories smaller than their state possessing significant supra-local governance capacity and cohesiveness differentiating them from their state and other regions'. Indeed, in many countries across the globe, the process of decentralization has strengthened considerably the local decision competencies and responsibilities. As long as such regions have autonomous spending capacities and decision-making powers, it seems natural for them to develop innovation policies at regional level.

The importance of regions for innovation policy is also prompted by those theories that feature the role of geographical proximity in facilitating local interactions and the diffusion of tacit knowledge, which is usually spatially bounded (Asheim and Gertler, 2005). At the same time, the focus on regions as a locus for innovation is motivated by the existence of large disparities between the countries, but also between the regions within a country, and the need to adopt differentiated policy interventions. This approach is strongly acknowledged and encouraged at the European Union (EU) level, whose innovation agenda is strongly intertwined with the EU Cohesion/ Regional policy. The European ambition is to close the innovation divide between the innovation leaders and the modest innovators and to reduce regional inequalities. As such, within the 2014-2020 programming period, the EU regions are called to develop smart specialization strategies (RIS3), as ex-ante conditionality for receiving EU funding for research and innovation.

A distinctive feature of smart specialization is its 'place-based' character underlining the need 'to develop and implement innovation strategies that take into proper account the regional features' (Foray et al., 2012). In fact, the use of different classification schemes that consider simultaneously the innovation potential and the regional features is highly recommended when elaborating the smart specialisation strategies.

So far, several classifications have been developed to capture both the regional innovation performance and other relevant territory-specific factors. For example, Muller et al. (2006) have created a regional typology of innovation capacities in the new member states and candidate countries along five dimensions: knowledge creation, absorptive capacity, diffusion capacity, demand and governance capacity. Dory (2008) has investigated two dimensions of the regional techno-economic systems, namely (i) the knowledge creation and absorption capacity and (ii) the economic structure and industrial specialisation, based on which he identified seven regional groupings with significant structural similarities. Navarro et al. (2008) have used 21 indicators reflecting the knowledge-generating inputs, the regional structural characteristics, the innovation output and the economic output and identified seven types of regional innovation systems across the EU-25. In a similar vein, Marsan and Maguire (2011) have created a categorisation of OECD regions using innovation-related vari- 
ables (e.g., R\&D inputs, linkages, innovation outputs and economic outcomes) and obtained a set of eight regional groupings. Capello and Lenzi (2013) have also created a taxonomy of European regions based on a list of indicators that cover the complex knowledge-innovation chain. Not least, the European Innovation Scoreboard (EC, 2019a) and the European Regional Innovation Scoreboard (EC, 2019b) distinguish between four different innovation performance groups and provide assessments of contextual data, to illustrate the potential impacts of structural differences on innovation performance.

Within this context, the aim of our paper is to examine the territorial innovation patterns in Romania, a post-communist country that joined the European Union in 2007 and is now a 'modest innovator' according to the European Innovation Scoreboard (EC, 2019a). Our main assumption is that there is large heterogeneity in the sub-national innovation patterns that is not captured in the existing typologies developed for the NUTS2 regions. The analysis is further justified by the fact that the NUTS2 divisions in Romania are not 'de facto' regions, as they do not actually have an administrative status. Consequently, we think that exploring the innovation patterns at a more granular level, namely at the NUTS3 ('county') level, gives a more nuanced perspective on innovation and structural conditions and can better inform the smart specialisation agenda.

To our knowledge, there is no similar investigation of the territorial innovation patterns in Romania, which may be explained, to a certain extent, by the limited availability of data. The rest of the paper is organized as follows: Section II introduces the conceptual framework and the variables used in the analysis; Section III is concerned with the methodology employed by the study to produce the categorization of the Romanian NUTS3 regions. The findings and the policy implications are presented in Section IV and the conclusion is reported in Section V.

\section{Conceptual framework}

The conceptual framework of our study is adapted from the European Innovation Scoreboard (EIS) and the European Regional Innovation Scoreboard (RIS) and relies on secondary data available for the NUTS3 level (Table 1; Annex 1). To produce the envisaged categorisation, we use a two-step factor analysis, as a data reduction method, combined with hierarchical cluster analysis.

In a first step, we investigate the territorial innovation performance based on 15 variables grouped into four dimensions. The 'Human Resources for R\&D' dimension captures the availability of doctorate and post-doctorate graduates and the supply of R\&D personnel, which are core inputs for the R\&D-based innovation. The 'R\&D Investments' dimension includes four variables that measure the total R\&D expenditures and the capacity to attract R\&D funds on a competitive basis from the National R\&D Plan and the European Framework Programme (FP7); as regards the FP7 data, we separate the funds granted to the public actors (universities, research organisations and governmental organisations) and to the private sector (companies and pri- 


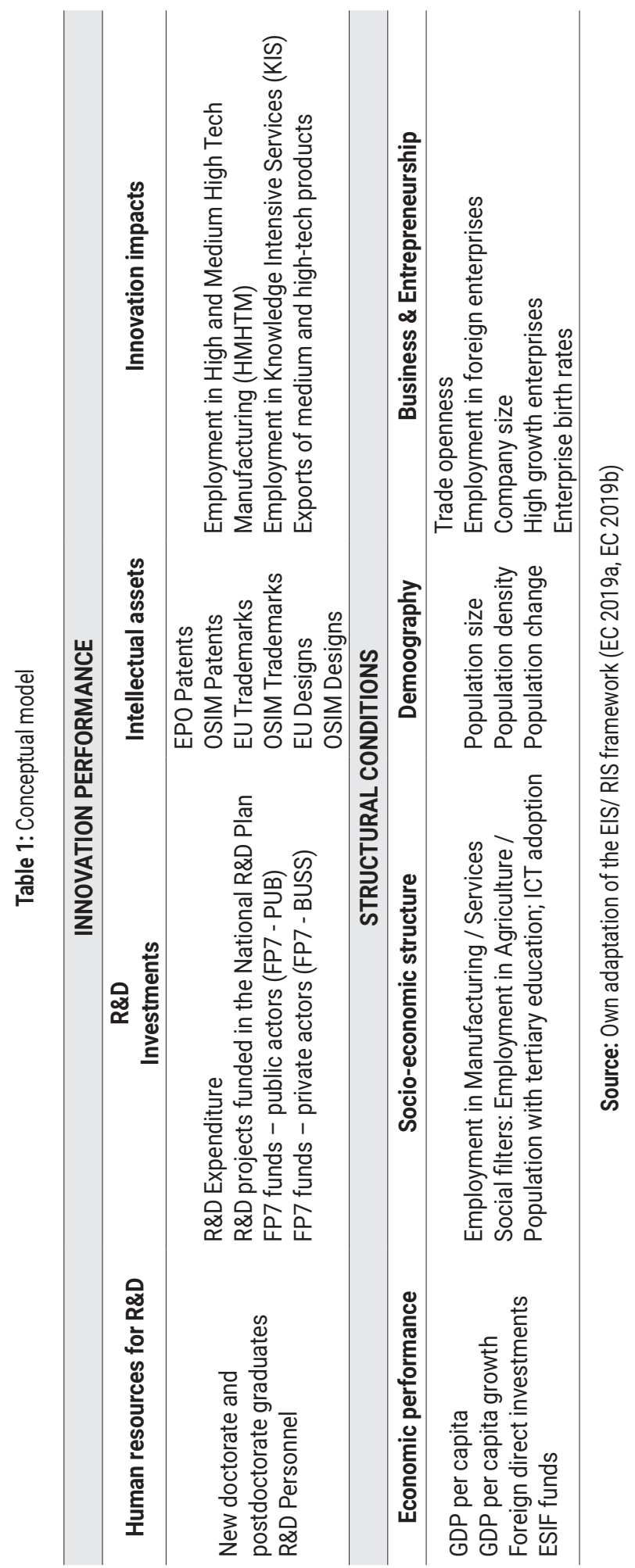


vate non-profit organisations), to keep up with the EIS/ RIS framework that differentiates between public and private R\&D. The 'Intellectual Assets' dimension captures the intellectual property (IP) activity in the form of Patent applications, Trademark applications and Design Applications; in this respect, we consider simultaneously the IP applications at the European Patent Office (EPO), the EU Intellectual Property Office and The (Romanian) State Office for Inventions and Trademarks (OSIM), as we have observed some territorial differentiations in the IP application behavior at the European vs. the national level. Finally, the 'Innovation Impacts' dimension captures the employment impacts, namely the Employment in High and Medium High Tech Manufacturing (HMHTM), the Employment in Knowledge Intensive Services (KIS) and the sales impacts, measured in Exports of medium and high-tech products.

Structural conditions are supposed to influence the current values and trends of innovation variables. In order to capture the regional structural features, we use 17 variables grouped into four dimensions. The first dimension covers the 'Economic performance' measured in GDP per capita (which is also a proxy for the demand for innovation), the change in GDP and the capacity to attract foreign direct investments (FDI) and European Structural and Investment (ESIF) Funds. The shares of employment in manufacturing and services are further used to reflect the 'Economic structure', together with two variables that capture the so-called 'social filters' (Rodriguez-Pose and Crescenzi, 2008), namely employment in agriculture and the share of population with tertiary education. At the same time, 'ICT adoption' is used as a proxy for digitalisation. Three socio-demographic variables are included in the analysis under the 'Demography' dimension, namely population size, population density and population change, as they are supposed to have a significant influence on the innovation performance. Finally, trade openness, company size, employment in foreign enterprises, the share of high growth enterprises and enterprise birth rates are further used to illustrate the 'Business and entrepreneurship' dimension.

A database was created with the selected variables measured as average over a five-year period (2014 - 2018) at the NUTS3 level (41 units), plus Bucharest Municipality; where data for the whole period were not available, the missing values were replaced with values of the last available year (Annex 1).

\section{Research method and results}

To produce the categorisation of the NUTS3 counties, we use a two-step factor analysis combined with hierarchical cluster analysis, in order to find a reduced number of independent latent variables and create a hierarchy of territorial innovation patterns. In a first step, the counties are categorized according to their innovation performance (Factor Analysis I) and the synthetic factors resulting from this iteration are further combined with the variables describing the structural conditions (Factor Analysis II). Similar to Muller et al. (2006), we apply this strategy to place superior weight on innovation performance in defining the typological distinctions. 
In the preparation phase, we have tested the linearity and factorability, which are key assumptions in factor analysis. The data was screened for outliers (the scores higher or lower than the mean plus three standard deviations) and the capital city Bucharest Municipality - was removed from analysis, as it has extremely high values for almost all the variables in the dataset. At the same time, for those variables where the degree of skewness was above one, the data have been transformed using a root square transformation (SQRT). We have also examined the correlation matrix and removed one variable - 'GDP per capita growth', as it was not correlated at least .3 with the other variables. This is in line with the findings in the dedicated literature: for instance, change in GDP correlates significantly and positively with only one indicator in the EIS 2018 (Cvijanovic et al., 2018).

\subsection{Factor Analysis I}

The factorability of the variables included in Factor Analysis I was examined using some well-recognized criteria: the diagonals of the antiimage correlation matrix were all over 0.7 ; the Kaiser-Meyer-Olkin measure of sampling adequacy was .848, which is above the commonly recommended value of 0.6 ; Bartlett's test of sphericity was significant $(\chi 2=640,653, \mathrm{p}<.05)$ and the communalities were all above .5 , thus confirming that each item shares some common variance with the other items. We have extracted the factors using the Principal Axis Factoring method and Varimax (orthogonal) rotation. The first three factors with initial eigenvalues higher than 1 explain cumulatively $75,264 \%$ of the variance (Table 2 ) and all of them are retained to be included in Factor Analysis II.

Table 2: Innovation performance - Total Variance Explained

\begin{tabular}{|c|c|c|c|c|c|c|c|c|c|}
\hline \multirow{2}{*}{ Factor } & \multicolumn{3}{|c|}{ Initial Eigenvalues } & \multicolumn{3}{|c|}{$\begin{array}{l}\text { Extraction Sums } \\
\text { of Squared Loadings }\end{array}$} & \multicolumn{3}{|c|}{$\begin{array}{l}\text { Rotation Sums } \\
\text { of Squared Loadings }\end{array}$} \\
\hline & Total & $\begin{array}{c}\% \text { of } \\
\text { Variance }\end{array}$ & $\begin{array}{l}\text { Cumula- } \\
\text { tive } \%\end{array}$ & Total & $\begin{array}{c}\% \text { of } \\
\text { Variance }\end{array}$ & $\begin{array}{l}\text { Cumula- } \\
\text { tive } \%\end{array}$ & Total & $\begin{array}{c}\% \text { of } \\
\text { Variance }\end{array}$ & $\begin{array}{l}\text { Cumula- } \\
\text { tive } \%\end{array}$ \\
\hline 1 & 8,551 & 57,045 & 57,045 & 8,339 & 55,593 & 55,593 & 5,941 & 39,607 & 39,607 \\
\hline 2 & 1,921 & 12,804 & 69,848 & 1,754 & 11,691 & 67,284 & 2,719 & 18,127 & 57,734 \\
\hline 3 & 1,465 & 9,767 & 79,615 & 1,197 & 7,980 & 75,264 & 2,630 & 17,530 & 75,264 \\
\hline
\end{tabular}

Extraction Method: Principal Axis Factoring

Source: The author

Table 3 displays the Rotated Factor Matrix and the factor loadings higher than 0.4. The variables included in the initial conceptual framework in the 'Human resources for R\&D' category and 'R\&D investments', but also 'Employment in KIS' have strong associations with Factor 1, that we call 'Knowledge generation (R\&D-based)' (1.1). Patent applications also have high loadings on factor 1, which reflects their R\&Dbased character. On the contrary, trademark applications and design applications have high loadings on Factor 2, that we call 'Non-technological innovation' (1.2) - 
given that trademarks are frequently used as proxies for non-technological innovation and / or innovation in services. Finally, 'Exports of medium and high-tech products' and 'Employment in HMHTM' have high loadings on the third factor - that we call 'Knowledge impact' (1.3). What is interesting to point here is the fact that the FP7 funds attracted by private actors have also significant loadings on this factor, which reflects, to some degree, the business-driven component of Romanian R\&D system.

Table 3: Innovation Performance - Rotated Factor Matrix ${ }^{a}$

\begin{tabular}{|c|c|c|c|}
\hline & \multicolumn{3}{|c|}{ Factor } \\
\hline & $\begin{array}{c}1.1 \\
\text { Knowledge generation } \\
\text { (R\&D-based) }\end{array}$ & $\begin{array}{c}1.2 \\
\begin{array}{c}\text { Non-technological } \\
\text { innovation }\end{array}\end{array}$ & $\begin{array}{c}1.3 \\
\text { Knowledge } \\
\text { impact }\end{array}$ \\
\hline R\&D projects - National R\&D Plan & 916 & & \\
\hline FP7 funds - Public & 911 & & \\
\hline Employment in knowledge-intensive services & 899 & & \\
\hline R\&D Personnel & ,834 & & \\
\hline Patents - OSIM & ,761 & & \\
\hline R\&D Expenditure & ,670 & & ,440 \\
\hline New doctorate and postdoctorate graduates & ,634 & & \\
\hline Patents - EPO & ,578 & & \\
\hline Trademarks - EU & & 872 & \\
\hline Designs - EU & & ,750 & \\
\hline Trademarks - OSIM & 635 & ,659 & \\
\hline Designs - OSIM & ,409 & ,570 & \\
\hline Exports of medium and high-tech products & & & ,924 \\
\hline Employment in HMHTM & & & ,909 \\
\hline FP7 funds - Private & ,485 & &, 509 \\
\hline
\end{tabular}

Extraction Method: Principal Axis Factoring; Rotation Method: Varimax with Kaiser Normalization.

a. Rotation converged in 6 iterations.

Source: The author

\subsection{Factor Analysis II}

The three factors resulting from Factor Analysis I were further considered in Factor Analysis II, together with the variables that describe the structural conditions. In the preliminary analysis, we removed the items with communalities $<.5$, namely 'ESIF Funds', 'Company size', 'High growth enterprises' and 'Enterprise birth rates', as they do not clearly differentiate between the innovation patterns. The Kaiser-MeyerOlkin measure of sampling adequacy was .833, indicating there are sufficient items for each variable; at the same time, Bartlett's test of sphericity was significant $(\chi 2=621,319, p<.05)$. Similar to Factor Analysis I, we have extracted the factors using the Principal Axis Factoring method and Varimax (orthogonal) rotation. The 
first three factors resulted from Factor Analysis II explain cumulatively 77,611\% of variance (Table 4).

Table 4: Innovation performance and structural conditions - Total Variance Explained

\begin{tabular}{|c|c|c|c|c|c|c|c|c|c|}
\hline \multirow{2}{*}{ Factor } & \multicolumn{3}{|c|}{ Initial Eigenvalues } & \multicolumn{3}{|c|}{$\begin{array}{l}\text { Extraction Sums } \\
\text { of Squared Loadings }\end{array}$} & \multicolumn{3}{|c|}{$\begin{array}{l}\text { Rotation Sums } \\
\text { of Squared Loadings }\end{array}$} \\
\hline & Total & $\begin{array}{c}\% \text { of } \\
\text { Variance }\end{array}$ & $\begin{array}{l}\text { Cumula- } \\
\text { tive \% }\end{array}$ & Total & $\begin{array}{c}\% \text { of } \\
\text { Variance }\end{array}$ & $\begin{array}{l}\text { Cumula- } \\
\text { tive } \%\end{array}$ & Total & $\begin{array}{c}\% \text { of } \\
\text { Variance }\end{array}$ & $\begin{array}{l}\text { Cumula- } \\
\text { tive \% }\end{array}$ \\
\hline 1 & 0,100 & 57,856 & & 7,886 & 56,328 & 56,328 & 4,304 & 30,742 & 30,742 \\
\hline 2 & 2,236 & 15,973 & 73,829 & 2,035 & 14,537 & 70,865 & 4,044 & 28,887 & 59,628 \\
\hline 3 & 1,165 & 8,324 & 82,153 &, 944 & 6,746 & 77,611 & 2,518 & 17,983 & 77,611 \\
\hline
\end{tabular}

Extraction Method: Principal Axis Factoring.

Source: The author

Table 5 shows the variables that have strong component loadings on each factor. One can easily observe that the three factors resulted from Factor Analysis I have the strongest loadings in the newly extracted factors, which is natural, as they are not inter-correlated. The first factor captures the 'Knowledge generation' (R\&Dbased) dimension (1.1.), which is strongly related to 'Population density', but also to 'Employment in services', 'Population with tertiary education', GDP per capita and FDI per capita, which are typical proxies for agglomerations; we therefore call this factor 'Agglomeration economies' (2.1). The 'Knowledge Impact' dimension (1.3.) loads very high on factor 2, together with 'Employment in manufacturing', 'Trade openness' and 'Employment in foreign companies', thus reflecting a clear pattern of specialization in manufacturing and HMHTM; we call this factor 'Industrial dynamics' (2.2). Finally, the 'Non-technological innovation' factor (1.2.) is positively correlated with 'Employment in Services' and 'Employment in Manufacturing', but negatively correlated with 'Employment in Agriculture', which is indicative of the territorial capacity to relocate the economic activities across sectoral borders; we therefore call this factor 'Structural transformation' (2.3), which is also closely linked to ICT adoption (digitalization) and the capacity to face the migration challenges (population change).

\subsection{Hyerarchical cluster analysis}

The three factors resulted from Factor Analysis II have been further used to categorise the Romanian NUTS3 counties by means of hierarchical cluster analysis. The strategy approach to devise these clusters was Ward method, to maximize the significance of differences between clusters; this is similar to OECD's categorisation of regions, which served as a benchmark to our study (Marsan and Maguire, 2011). As shown in the Dendrogram (Annex 2), the analysis resulted in the creation of different regional groupings (Euclidean distance $<5$ ) that further combine into five large macro-regional clusters (Euclidean distance $=5$ ), based on their structural similarities; Annex 3 introduces the clusters' means (standardized). 
Table 5: Innovation performance \& Structural Conditions - Rotated Factor Matrix ${ }^{a}$

\begin{tabular}{|c|c|c|c|}
\hline & \multicolumn{3}{|c|}{ Factor } \\
\hline & $\begin{array}{c}2.1 \\
\text { Agglomeration } \\
\text { economies }\end{array}$ & $\begin{array}{c}2.2 \\
\text { Industrial } \\
\text { dynamics }\end{array}$ & $\begin{array}{c}2.3 \\
\text { Structural } \\
\text { transformation }\end{array}$ \\
\hline $\begin{array}{l}\text { REGR factor score } 1 \text { for analysis } 1 \\
\text { (Knowledge generation, R\&D-based) }\end{array}$ &, 920 & & \\
\hline Employment in Services & ,773 & &, 512 \\
\hline Population change & ,666 & & ,475 \\
\hline Population density & ,663 & & \\
\hline Population with tertiary education & ,658 &, 524 & \\
\hline Foreign direct investments & 648 &, 482 & \\
\hline GDP per capita & ,626 &, 522 & \\
\hline $\begin{array}{l}\text { REGR factor score } 3 \text { for analysis } 1 \\
\text { (Knowledge impact) }\end{array}$ & & 975 & \\
\hline Employment in Manufacturing & & ,769 &, 420 \\
\hline Trade openness & ,485 & ,754 & \\
\hline Employment in foreign companies & & ,714 & \\
\hline $\begin{array}{l}\text { REGR factor score } 2 \text { for analysis } 1 \\
\text { (Non-technological innovation) }\end{array}$ & & & ,804 \\
\hline ICT adoption (digitalisation) & ,441 & ,455 & 611 \\
\hline Employment in Agriculture &,- 415 &,- 572 &,- 581 \\
\hline
\end{tabular}

Extraction Method: Principal Axis Factoring; Rotation Method: Varimax with Kaiser Normalization. a. Rotation converged in 4 iterations.

Source: The author

Cluster A ('Knowledge-intensive hubs') includes four counties - Cluj, Timiș, Iași and Ilfov. The latter can be seen as a 'satellite' of Bucharest and should be addressed in conjunction with the capital city ${ }^{1}$, which displays the highest innovation performance and the most favourable socio-economic conditions. Overall, the counties belonging to Cluster A have the highest score on the 'Agglomeration economies' dimension and for employment in KIS. Employment in HMHTM is below the national average, but exports of medium and high-tech products are high, which is indicative of an outstanding productivity. The counties in Cluster A have the best performance on knowledge generation - both R\&D-based and non-technological - and are very successful in attracting money (R\&D funding, FDI, ESIF funds, new enterprises), talents and people into the region. They also have the most educated workforce and are experiencing positive population change. Timiș is better placed on the 'Industrial dynamics' dimension, which is the main strength of the counties in Cluster B; yet, as

1 Bucharest Municipality, which initially was excluded from the analysis, as it was an outlier case, now joined this group. 
compared to the Technology-intensive platforms, Timiș has a more dynamic KIS sector and is better placed to progress to the knowledge frontier. In its turn, Iași diverges to some extent from the picture, as it has below average levels of FDI and GDP per capita, which is common to all the counties in the North-East region; nevertheless, it is still included in this Cluster due to its strong R\&D base (particularly public R\&D) and its well-developed innovation potential.

Cluster B ('Technology-intensive platforms') is composed of four NUTS3, namely Brașov, Argeș, Sibiu and Arad and is leading in the 'Industrial dynamics' dimension. The group displays the highest share of employment in HTMHT, coupled with medium-to-high shares of employment in KIS; it has outstanding performances in exports of medium and high-tech products, which are associated with the highest rate of trade openness and employment in foreign and large enterprises. The group comes second in terms of innovation performance (after Cluster A) and has above average performances for R\&D expenditure and FP7 funds attracted by the private actors. Economic performance is strong and the counties have high technological readiness, a large proportion of population with tertiary education and a mild population decline. Cluster $B$ is much stronger in private $R \& D$ than in public $R \& D$ and is less performant in attracting ESIF funds, which may reflect a potential trade-off between the presence of large companies and the ESIF rules.

Cluster C ('Diversified agglomerations') includes three NUTS3, namely Dolj, Constanța and Galați, all scoring high on the 'Aggolmeration economies' dimension; they are large and densely populated regions, with above average employment in services and KIS, in combination with below average employment in manufacturing and HTMHT. The innovation component is moderate when compared to Clusters A and B. All the counties in this group host universities and/or R\&D centers, but they have a bias towards the national R\&D funds and the application for intellectual assets at the national (not the European) level. Economic performance is above average and the counties do meet the pre-conditions for progress towards knowledge-based growth trajectories, i.e. they have a relatively well-educated population, medium trade openness, positive entrepreneurial dynamics and high capacity to attract ESIF Funds. Dolj is better placed on the 'Industrial dynamics' dimension, but is still far from being part of Cluster B ('Technology-intensive platforms'), as its economic structure is strongly dominated by agriculture, while manufacturing and the HTMHT sectors are not firmly embedded in the region.

Cluster D ('Industrial production zones') is composed of 11 counties that may be further divided into two main regional groupings. Cluster $\mathrm{D}$ is characterized by large employment in manufacturing, coupled with average employment in services. In a comparative perspective, the group has modest scores for the R\&D-based innovation component, but has a good record in producing non-technological innovation and in exporting medium and high tech products. Their economic performance is average, but there are some promising growth routes sourced by the trade openness, the large presence of foreign companies and the relatively well-educated workforce. The first 
sub-group comprises six counties (Prahova, Mureș, Maramureș, Bihor, Covasna and Harghita) whose distinctive features are the above average employment in services and the propensity towards applications for trademarks and designs at the EU level, which may be translated in a promising potential for spreading non-technological innovations across borders. The second group consists of five counties (Alba, Hunedoara, Satu Mare, Bistrița-Năsaud and Sălaj), which are stronger in manufacturing and HTMHT and have a good export performance. Alba and Bistrița-Năsăud are potential candidates for Cluster B ('Technology-intensive platforms'), on the condition that they succeed to increase their R\&D intensity, which is currently well below average.

Cluster F ('Structurally-challenged regions') includes 19 counties that display high shares of employment in agriculture, in combination with below average innovation and economic performance. These counties suffer from important structural deficiencies, i.e. the share of population with tertiary education is very low and so is the case for FDI and GDP per capita, ICT adoption and trade openness; in addition, most of these counties are seriously affected by population decline, which poses huge challenges to their future growth paths. The Dendrogram (Annex 2) differentiates between two sub-groups within this Cluster, but the differences between the two are reduced (Euclidean distance $<5$ ). Among the 'Structurally challenged regions', there are some emerging candidates for other groups, whose innovation performance is currently higher than that of their counterparts, i.e. Suceva has the potential to advance towards the Diversified agglomerations (Cluster C), while Tulcea, Vâlcea, Caraș-Severin and Dâmbovița are potential candidates for the Industrial production zones (Cluster D). For such an advancement to occur, the condition is to get rid of the social filters, increase the absorption capacity and accelerate structural transformation. Figure 1 represents the five Clusters on Romania's NUTS3 map.

\section{Policy implications for smart specialization}

Our results confirm the heterogeneity in innovation performance and structural conditions at the sub-national level in Romania and bring up a number of implications for the innovation policy and the design of smart specialisation strategies.

Overall, our findings show that the potential for knowledge generation and R\&Dbased innovation is concentrated in large and densely populated agglomeration economies, with high levels of employment in KIS and a highly skilled workforce. On the other hand, a pattern of non-technological innovation emerges in those regions that have a balanced sectoral distribution and high absorption capacity to take advantage of the knowledge inflows coming from foreign companies, trade partners or from other (knowledge) regions; in other words, these are the regions that are successfully embracing structural transformation. Not last, a third innovation pattern emerges in those counties with large employment in HTMHT, which benefit extensively from the relocation of Western industries and are now Romania's export 'champions'; yet, the innovation component of this pattern is weak where foreign companies are not 


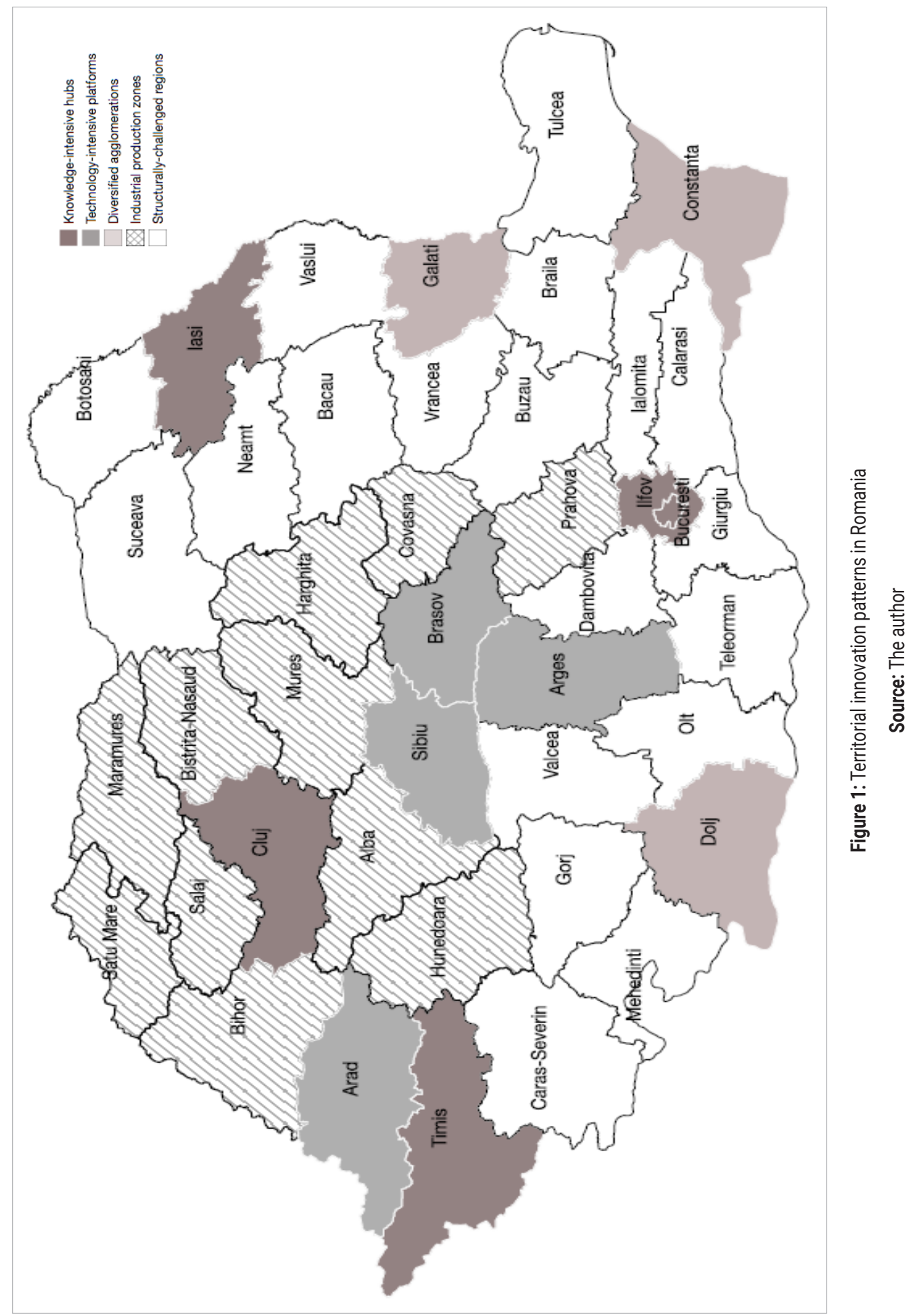


strongly embedded and connected to local economies. At the intersection of these patterns, we found five main territorial groupings - knowledge-intensive hubs, technology-intensive platforms, diversified agglomerations, industrial production zones and structurally challenged regions - each of them in need of differentiated policy interventions.

The Knowledge-intensive hubs concentrate the best potential in innovation and economic performance and can be considered Romania's 'pockets of excellence'. In the European policy context, the 'pockets of excellence' are 'local or regional research or innovation eco-systems, in countries with an overall weaker R\&D and innovation system, which prove capable of driving regional growth and of linking up to top-European research networks' (Reid, Markianidou and Evrigenis, 2015). For such regions, the main policy goal is to reinforce excellence in science and technology (OECD, 2011), while supporting thematic concentration of public support in few niche areas, preferably in general-purpose or key-enabling technology fields. Knowledge-intensive regions are expected to be active in international competitive RDI programs, create synergies between ESIF Funds and other European programs (Horizon-like) and strengthen their position in international knowledge networks.

In their turn, the Technology-intensive platforms have a critical mass of $R \& D$ endowment, coupled with very strong production capabilities, particularly in the HMHTM sectors. The main policy goal for this group is to strengthen the R\&D base and create synergies between science and technology and production activities (OECD, 2011). These counties are expected to differentiate themselves within the international value chains in which they are already involved. Attracting more ESIF funds than in the previous programming periods is providential in strengthening the $\mathrm{R} \& \mathrm{D}$ and technological infrastructure; at the same time, enhancing participation in European research and innovation progammes could facilitate the access to more advanced knowledge and state-of-the-art technological advancements.

For the Diversified agglomerations, the main challenge is to better exploit their agglomerative potential, i.e. the relatively strong KIS sector, the strong pool of doctorate and postdoctorate graduates or the presence of foreign direct investments. Given their diversified character, such regions should clearly define, through entrepreneurial discovery processes, the most promising knowledge-based growth avenues and give particular attention to their competitive advantages. In order to move forward, the Diversified agglomerations are expected to support clearly defined innovation trajectories and reinforce their leadership in particular areas. Of crucial importance for these counties is to have a focus not only on national R\&D and ESIF funds, but also on increasing participation in European and international programs and initiatives.

Industrial production zones do not perform as R\&D-based centers, but have current advantages on which to build on the smart specialization strategies. With a strong industrial fabric and relatively skilled population, these counties are expected to modernise their productive activities towards value-added niches (OECD, 2011). In 
this respect, they may consider incremental innovation, quality improvements, technological upgrading or the enhancement of production capabilities and management practices (Foray, Morgan and Radosevic, 2018). One important policy challenge for the Industrial production zones is to anchor the multinational companies to the territory, for example, by means of cluster policies or collaborative innovation-oriented programs. Reinforcing access to know-how through participation in European networks, partnerships and value chains could also be highly beneficial to move forward these types of regions.

Finally, the Structurally challenged regions seem to have the most difficult mission in their transition to the knowledge-based economy, as they have poor innovation capacity and face persistent underdevelopment traps. The main policy goal to such regions is to accelerate structural transformation, while stimulating knowledge absorption and entrepreneurial dynamism (OECD, 2011). From a smart specialisation perspective, structurally challenged regions are expected to identify the areas in which they have comparative advantages and target even the low-tech and traditional sectors (agri-food, tourism, textiles etc.) through incremental innovation. Getting rid of the social filters that hinder innovation is a challenge that may be addressed by means of investments in education and human capital (to increase the absorptive capacity), digitalisation, infrastructure network, industrial restructuring and business support. In this respect, policy-making should carefully consider the synergies between the different types of ESIF funds, i.e. the European Regional Development Fund, the European Social Fund, the European Agriculture and Rural Development Fund.

Apart from these specific territorial implications, at least five general conclusions can be drawn from our analysis.

\section{1. $R \& D$ resources in Romania are scarce and extremely polarized}

Romania's investment in research and development is the lowest in the European Union and the RDI system is chronically underfunded, fragmented and unpredictable (Chioncel and Del Rio, 2018). According to Goschin, Sandu and Goschin (2015), the time span required to fill Romanian R\&D's system gap against the EU varies between 5 and 25 years depending on the indicators considered. The country has a low participation in FP7, with Bucharest, Cluj, Iași, Timiș and Brașov being the five most significant recipients of $R \& D$ funding (Curaj, 2015). The high concentration of $R \& D$ resources in also evident from our analysis, where the Knowledge-intensive hubs (Cluster 1) concentrate more than two thirds of total R\&D personnel (70\%), total R\&D expenditure (77\%), FP7 Funds granted to public actors (87\%) etc. Acknowledging R\&D as a priority sector, increasing the $\mathrm{R} \& \mathrm{D}$ expenditure and reducing the enormous disparities in R\&D-based innovation are fundamental challenges to be addressed in the years to come. 


\subsection{Foreign-owned companies are important players in the Romanian innovation system}

Foreign-owned companies account for about $70 \%$ of Romanian exports and concentrate more than two thirds of the value added in the automotive sector $(+90 \%)$, manufacturing of computer, electronic and optical products $(+70 \%)$, manufacturing of electrical equipment, $(+70 \%)$, telecommunications $(70 \%)$ etc. (Horobeț and Popovici, 2017). In our study, foreign direct investments are positively associated with agglomeration economies, while employment in foreign companies is among the main drivers of exports of medium and high-tech products. However, the correlation with R\&D expenditure is only moderate, which means that the foreign-owned companies are not strongly embedded in the Romanian RDI system. In this respect, there is evidence that several multinational companies - especially in the automotive and IT sectors - have set up R\&D centers in Romania, but they are primarily concerned with experimental development rather than industrial research (European Commission, 2019c). Further efforts are thus needed to stimulate technology spillovers and facilitate the access to international value chains, via the foreign enterprises established in Romania.

\subsection{Structural conditions explain to a large extent the differences in innovation and economic performance}

13 years after joining the European Union, Romania is one of the fastest growing European economies and the forecasts indicate that the GDP per capita will reach $66.3 \%$ of the EU average in 2022 (Albu et al., 2018). Nevertheless, the sectoral composition of the Romanian economy is still different from that of the EU and Romania is seriously lagging behind in terms of labor productivity, especially in the agricultural sector (European Commission, 2019c). Alternatively, as evidenced by our study (Table 5), employment in agriculture has negative correlations with all the variables that describe the innovation performance. Consequently, continuing the sectoral transformation of the economy, 'through a rational correlation between tertiarisation and basic branches and by expansion of technologically leading industries' (Dobrescu, 2018) is one of Romania's main challenges in the future. Investments in infrastructure, digitalization and ICT, decarbonification, circular economy etc. (Albu et al., 2018) are key drivers for boosting Romania's competitiveness in Europe and beyond.

\subsection{Population decline threatens Romania's future growth prospects}

Romania's population has declined dramatically in recent years, due to emigration, fast ageing and low birth rates (European Commission, 2019c). The OECD (2019) estimates that the Romanian diaspora is the fifth largest in the world and that close to a fourth of Romanian emigrants in the OECD countries are highly educated (OECD, 2018). In our analysis, population decline is much larger for the Structurally challenged regions (Cluster D), thus posing additional challenges in terms of labor and skills shortages. With only about a quarter of the population aged 30-34 having a 
tertiary degree (vs. $40 \%$ at the EU level) and significant brain drain, Romania's growth prospects are seriously threatened, the more that the impact of human capital on economic growth is estimated to be higher in Romania $(0,40)$ than at the EU level $(0,25)$ (Pelinescu et al., 2019). Addressing coherently the brain drain phenomenon (Chioncel and Del Rio, 2018), facilitating the repatriation of the Romanian emigrants (Dobrescu, 2018) and investing in skills as a 'no-regrets' policy (Farole, Goga and Ionescu-Heroiu, 2018) appear as priority policy actions.

\subsection{Quality of governance is of major importance in stimulating innovation and driving smart specialization}

There is large agreement in the literature that institutions matter for regional development and that a low quality of government strongly undermines the capacity of regions to innovate and to make smart specialization strategies work (Rodriguez-Pose, di Cataldo and Rainoldi, 2014). Similar to other countries in Central and Eastern Europe, Romania has a fragile institutional framework, which threatens the successful implementation of the smart specialization agendas and the efficient use of Cohesion policy investments (Foray, Morgan and Radosevic, 2018). Romania is part of the bottom-up group in the European Quality of Governance Index, together with Bulgaria and Greece (Charron and Lapuente, 2018) and suffers from important institutional deficits; the country is highly centralized, has no-formal regional RDI policies and has difficulties in coordinating regional and national smart specialization processes (Ranga, 2018). At the same time, the perception of the Government Capacity to Perform (GCP) is one of the lowest in the EU and it followed a downward trend between 2009 and 2016 (Țigănaşu, Pascariu and Nijkamp, 2019). With a view to the next multi-annual financial framework 2021-2027, consolidating the multilevel governance structure and the coordination between various sectoral policies are among the most important prerequisites for a more ambitious innovation agenda.

\section{Conclusions}

This study produced a categorisation of Romanian NUTS3 counties according to their innovation performance and structural characteristics, which may help design differentiated policy interventions. Taken together, the results suggest that the R\&D-based innovation potential is concentrated in a few 'pockets of excellence' that should be further integrated in international networks and value chains and transformed into service-centers to all the other regions.

The evidence from our analysis suggests that structural features have a strong explanatory power for innovation, which calls for a broadly defined innovation policy (Tsipouri, 2018) that considers multiple modes of innovation and supports 'a broader range of transformational processes' (Foray, Morgan and Radosevic, 2018). Future studies on the current topic are needed to increase our understanding of the patterns of non-technological innovation in Romania, but also to estimate the impact of innovation policies, smart specialization and ESIF investments at the territorial level. 


\section{References:}

1. Albu, L.L., Lupu, R., Calin, A.C. and Popovici, O., 'Impactul aderării României la Uniunea Europeană asupra economiei românești. Analiză sectorială’ [The Impact of Romania's Accession to the European Union on the Romanian Economy. Sector Analysis], Studii de Strategie și Politici SPOS 2017, no 1, Bucharest: Institutul European din România, 2018, [Online] available at http://ier.gov.ro/wp-content/uploads/2018/10/SPOS_2017_Studiul-1_ FINAL.pdf, accessed on August 12, 2020.

2. Asheim, B. and Gertler, M., 'The Geography of Innovation: Regional Innovation Systems', in Fagerberg, J., Mowery, D. and Nelson, R. (eds.), The Oxford Handbook of Innovation, Oxford: Oxford University Press, 2005, pp. 291-317.

3. Capello, R. and Lenzi, C., 'Territorial Patterns of Innovation: A Taxonomy of Innovative Regions in Europe', 2013, The Annals of Regional Science, vol. 51, no. 1, pp. 119-154.

4. Charron, N. and Lapuente, V., 'Quality of Government in EU Regions: Spatial and Temporal Patterns', QoG Working Paper Series, 2018:2, Goteborg: The Quality of Government Institute, 2018.

5. Chioncel, M. and Del Rio, J.C., 'RIO Country Report 2017: Romania', Joint Research Centre, Luxembourg: Publications Office of the European Union, 2018, [Online] available at https://rio.jrc.ec.europa.eu/en/country-analysis/Romania/country-report, accessed on August 20, 2020.

6. Curaj, A., 'Stairway to Excellence Country Report: Romania', JRC Working Papers JRC97667', Seville: Joint Research Centre, 2018, [Online] available at https://publications. jrc.ec.europa.eu/repository/handle/JRC97667, accessed on August 20, 2020.

7. Cooke, P., Gomez Uranga, M. and Etxebarria, G., 'Regional Innovation Systems: Institutional and Organizational Dimensions', 1997, Research Policy, vol. 26, no. 4-5, pp. 475-491.

8. Cvijanovic, V., Elci, S., Reid, A. and Hollanders, H., 'European Innovation Scoreboard 2018. Exploratory Report C: Supplementary Analyses and Contextualisation of Innovation Performance Data', Bruxelles: European Commission, 2018.

9. Dobrescu, D., 'A New Version of the Romanian Macromodel - Aggregate System', 2018, Romanian fournal of Economic Forecasting, vol. XXI, no. 4, pp. 5-20.

10. Dory, T., 'RTD Policy Approaches in Different Types of European Regions', JRC, Institute for Prospective Technological Studies and the DG Research, Luxembourg: Office for Official Publications of the European Communities, 2008, [Online] available at https:// publications.jrc.ec.europa.eu/repository/bitstream/JRC45086/jrc45086.pdf, accessed on August 2, 2020.

11. European Commission, 'European Innovation Scoreboard 2019 - Methodology Report', 2019a, [Online] available at https://ec.europa.eu/docsroom/documents/36282, accessed on August 20, 2020.

12. European Commission, 'Regional Innovation Scoreboard 2019 - Methodology Report', 2019b, [Online] available at https://ec.europa.eu/docsroom/documents/37783, accessed on August 20, 2020.

13. European Commission, '2019 European Semester. Country Report - Romania 2019 Including an in-Depth Review on the Prevention and Correction of Macroeconomic Imbalances', SWD(2019) 1022 final, Bruxelles: European Commission, 2019c. 
14. Farole, T., Goga, S. and Ionescu-Heroiu, M., 'Rethinking Lagging Regions', World Bank Report for the European Union, Washington, DC: International Bank for Reconstruction and Development / The World Bank, 2018.

15. Foray, D., Goddard, J., Beldarrain, X.G., Landabaso, M., McCann, P., Morgan, K., Nauwelaers, C. and Ortega-Argiles, R., 'Guide to Research and Innovation Strategies for Smart Specialisation (RIS3)’, Brussels: European Commission, 2012.

16. Foray, D., Morgan, K. and Radosevic, S., 'The Role of Smart Specialization in the EU Research and Innovation Policy Landscape', DG Regio Working Paper, Brussels: European Commission, 2018.

17. Goschin, Z., Sandu, S. and Goschin, G.G., 'How Soon Could Romania Close the R\&D Gaps Against EU-28?', 2015, Procedia Economics and Finance, vol. 22, pp. 160-167.

18. Horobeț, A. and Popovici, O., 'Investițiile Străine Directe: Evoluția și importanța lor în România' [Foreign Direct Investments: Their Evolution and Importance in Romania], Academia de Studii Economice București și Consiliul Investitorilor Străini [Bucharest Academy of Economic Studies and the Council of Foreign Investors], 2017, [Online] available at https://fic.ro/Documents/view/Studiu-Investitiile-straine-directe-evolutia-siimportanta-lor-in-Romania, accessed on August 13, 2020.

19. Marsan, A.G. and Maguire, K., 'Categorisation of OECD Regions Using Innovation-Related Variables', OECD Regional Development Working Papers, no. 2011/03, Paris: OECD Publishing, 2011.

20. Muller, E., Jappe, A., Heraud, J. and Zenker, A., 'A Regional Typology of Innovation Capacities in New Member States \& Candidate Countries', Working Papers Firms and Region, no. R1, Karlsruhe: Frauenhofer ISI, 2006.

21. Navarro, M., Gibaja, J.A., Bilbao-Osorio, B. and Aguado, R., 'Patterns of Innovation in EU25 Regions: A Typology and Policy Recommendations', 2009, Environment and Planning C: Government and Policy, vol. 27, no. 5, pp. 815-840.

22. OECD, 'Regions and Innovation Policy', OECD Reviews of Regional Innovation, Paris: OECD Publishing, 2011.

23. OECD, 'Talent Abroad: A Review of Romanian Emigrants', Paris: OECD Publishing, 2009.

24. Pelinescu, E., Pauna, C., Saman, C. and Diaconescu, T., 'Human Capital, Innovation and Economic Growth in the EU Countries', 2019, Romanian fournal of Economic Forecasting, vol. XXII, no. 4, pp. 160-173.

25. Ranga, M., 'Smart Specialization as a Strategy to Develop Early-Stage Regional Innovation Systems', 2018, European Planning Studies, vol. 26, no. 11, pp. 2125-2146.

26. Reid, A., Markianidou, P. and Evrigenis, A., 'Pockets of Excellence with Innovation Potential', A Study for the EC DG Research \& Innovation, Brussels: European Commission, 2015.

27. Rodriguez-Pose, A. and Crescenzi, R., 'Research and Development, Spillovers, Innovation Systems, and the Genesis of Regional Growth in Europe', 2008, Regional Studies, vol. 42, no. 1, pp. 51-67.

28. Rodriguez-Pose, A., di Cataldo, M. and Rainoldi, A., 'The Role of Government Institutions for Smart Specialisation and Regional Development', S3 Policy Brief Series, no. 04/2014, Seville: Joint Research Centre. 
29. Țigănașu, R., Pascariu, G.C. and Nijkamp, P., 'Performance and Innovation in the Public Sector of the European Union Countries. An Analysis Based on the Dynamics of Perceptions, 2009-2016', 2019, Transylvanian Review of Administrative Sciences, Special Issue, pp. 94-123.

30. Tsipouri, L., 'Fostering Innovation in Less-developed and Low Institutional Capacity Regions: Challenges and Opportunities', Background paper for an OECD/ EC Workshop on 22 June 2018, within the workshop series 'Broadening Innovation Policy: New Insights for Regions and Cities', Paris: OECD, 2018. 
Annex 1: List of variables and data sources

\section{Variables}

Doctorate and post-doctorate graduates per milion population aged 25-34 years

R\&D personnel per 10000 employed persons $R \& D$ expenditure, $\%$ of GDP

Number of R\&D projects granted to $R \& D$ actors, per population

FP7 funds - Public actors (universities, research organisations) per population FP7 funds - Private actors (companies, non-profit organisations) per capita Number of patent applications to the EPO per million inhabitants Number of patent applications at OSIM per 100000 inhabitants Number of EU Trademark applications per million inhabitants

Number of Trademark registration applications at OSIM per 100000 inhabitants Number of Community design applications per million inhabitants

Number of Designs registration applications at OSIM per 100000 inhabitants

Share of employees in High and Medium High Tech Manufacturing (HMHTM) in total employees

Share of employees in knowledge intensive services (KIS) in total employees

Share of Exports of medium and high-tech products in total exports.

Gross Domestic Product (GDP): Purchasing power standard (PPS) per inhabitant Compound Average Growth Rate (CAGR) of GDP per capita

FDI Stock per capita

European Structural and Investment Funds thousand lei per capita

Employment share in Manufacturing, $\%$ total employment
Data sources

The National Institute of Statistics in Romania (NIS): Graduates by level of education; Eurostat: Population on 1 January by age group by NUTS3

NIS: Total R\&D personnel per 10000 employed persons

NIS: Total R\&D expenditure;

Eurostat: GDP at current market prices

UEFISCDI: Map of projects funded within National RDI Plan II and III; Eurostat: Population on 1 January by NUTS3 CORDIS: Research projects under FP7 (2007-2013); Eurostat: Population on 1 January by NUTS3 CORDIS: Research projects under FP7 (2007-2013); Eurostat: Population on 1 January by NUTS3 Eurostat: Patent applications to the EPO by priority year by NUTS3

OSIM: Number of patent applications by counties, per 100,000 inhabitants

Eurostat: European Union trade mark applications by NUTS3

OSIM: Number of trademarks registration applications by counties, per 100,000 inhabitants

Eurostat: Community design (CD) applications by NUTS3

OSIM: Number of Designs registration applications, by counties, per 100,000 inhabitants

NIS: Employees by economic activities at NACE Rev. 2 level. Own aggregation of HMHTM based on NACE Rev. 2: 20, 21, 26-30

NIS: Employees by economic activities at NACE Rev. 2 level. Own aggregation of KIS based on NACE Rev. 2: 50-51, section J, K, M, O, P, Q, R

NIS: Export value (FOB) by counties and by sections/ chapters of the Combined Nomenclature. Own aggregation based on OECD/ Technological classification of exports - Chapter VI, Section 39, Chapter XVI, XVII, XVIII (Musical instruments not included)

Eurostat: GDP at current market prices by NUTS 3

Eurostat: GDP at current market prices by NUTS3

National Bank of Romania: FDI in Romania in 2018; Eurostat: Population on 1 January by NUTS3 Ministry of European Funds: Signed contracts for European projects by counties; Eurostat: Population on 1 January by NUTS3

NIS: Civil employment, by activity of national economy at level of NACE section (NACE C) 


\section{Variables}

Employment share in Services,

$\%$ total employment

Employment share in Agriculture, $\%$ total employment

Share of population aged 30-34 y having completed tertiary education by total population aged 30-34 y

ICT adoption: population aged 10 years and over using Internet, \% of population aged 10 years and over

Population size by NUTS3 regions

Population density by NUTS3 regions

Crude rate of total population change

Trade openness: sum of imports and exports normalized by GDP

Enterprise size: no of employees

per active enterprises

Employees in foreign controlled enterprises, $\%$ of total employees

Share of high growth enterprises measured in employment in industry, construction and services

Enterprise birth rates: Number of enterprise births divided by the number of enterprises active in industry, construction and services

\section{Data sources}

NIS: Civil employment, by activity of national economy at level of NACE section (NACE G-N)

NIS: Civil employment, by activity of national economy at level of NACE section (NACE A)

NIS - Census 2011: Stable population aged 10 and over by group age

NIS - Census 2011: Population aged 10 years and over using Internet

Eurostat: Population on 1 January by NUTS3

Eurostat: Population density by NUTS3

Eurostat: Population change, Demographic balance and crude rates by NUTS3

NIS: Exports (FOB) and Imports (CIF) by sections; Eurostat: GDP at current market prices

Eurostat: Employer business demography by size class and NUTS3

NIS: Average number of employees by ownership type, macroregion, development region and county

Eurostat: Business demography

and high growth enterprise by NACE Rev. 2

Eurostat: Business demography

and high growth enterprise by NACE Rev.2 
Annex 2: Dendrogram

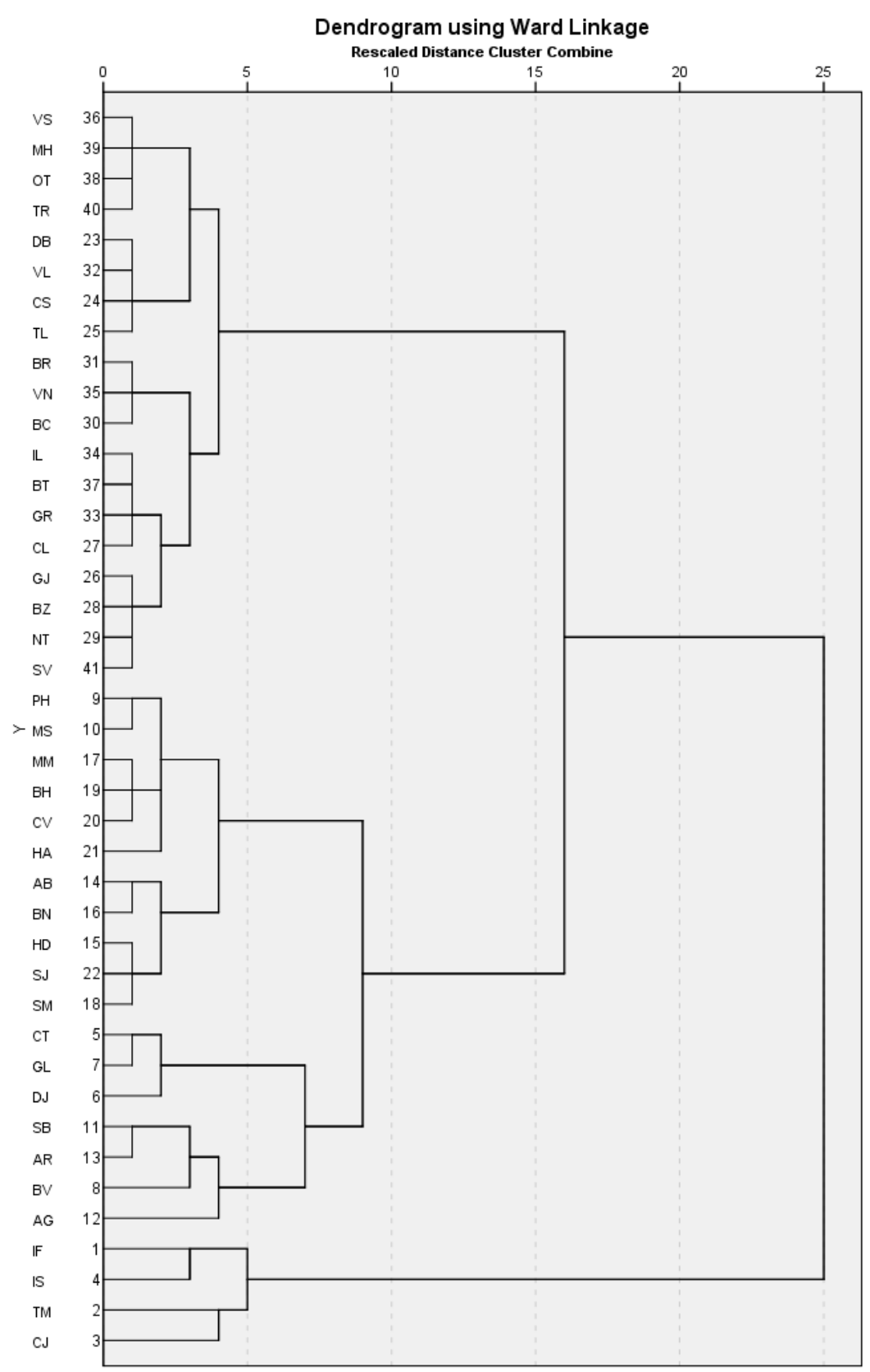


Annex 3: Clusters' means (standardized)

\begin{tabular}{|c|c|c|c|c|c|}
\hline Variables & Cluster A & Cluster B & Cluster C & Cluster D & Cluster $\mathbf{E}$ \\
\hline New doctorate and postdoctorate graduates & 1,00 & 0,21 & 0,33 & 0,10 & 0,02 \\
\hline R\&D Personnel & 1,00 & 0,52 & 0,35 & 0,07 & 0,08 \\
\hline R\&D Expenditure & 1,00 & 0,52 & 0,07 & 0,06 & 0,07 \\
\hline R\&D Projects - National R\&D Plan & 1,00 & 0,14 & 0,17 & 0,05 & 0,03 \\
\hline FP7 Funds - Public & 1,00 & 0,11 & 0,11 & 0,01 & 0,02 \\
\hline FP7 Funds - Private & 1,00 & 0,58 & 0,16 & 0,20 & 0,07 \\
\hline Patents - EPO & 1,00 & 0,31 & 0,12 & 0,17 & 0,07 \\
\hline Patents OSIM & 1,00 & 0,34 & 0,32 & 0,19 & 0,21 \\
\hline Trademarks EU & 1,00 & 0,29 & 0,13 & 0,25 & 0,07 \\
\hline Trademarks OSIM & 1,00 & 0,36 & 0,29 & 0,24 & 0,13 \\
\hline Designs EU & 1,00 & 0,28 & 0,13 & 0,46 & 0,11 \\
\hline Designs OSIM & 1,00 & 0,30 & 0,50 & 0,35 & 0,18 \\
\hline Employment in HMHTM & 0,39 & 1,00 & 0,24 & 0,40 & 0,26 \\
\hline Employment in knowledge-intensive services & 1,00 & 0,44 & 0,52 & 0,32 & 0,32 \\
\hline Exports of medium and high-tech products & 0,41 & 1,00 & 0,15 & 0,20 & 0,05 \\
\hline GDP per capita & 1,00 & 0,72 & 0,65 & 0,55 & 0,44 \\
\hline GDP per capita growth* & 0,81 & 1,00 & 0,67 & 0,92 & 0,77 \\
\hline Foreign direct investments & 1,00 & 0,38 & 0,25 & 0,19 & 0,08 \\
\hline ESIF Funds* & 1,00 & 0,24 & 0,63 & 0,39 & 0,28 \\
\hline Employment in Manufacturing & 0,62 & 1,00 & 0,49 & 0,84 & 0,56 \\
\hline Employment in Services & 1,00 & 0,75 & 0,78 & 0,65 & 0,57 \\
\hline Employment in Agriculture & 0,41 & 0,43 & 0,72 & 0,69 & 1,00 \\
\hline Population with tertiary education & 1,00 & 0,77 & 0,69 & 0,57 & 0,45 \\
\hline ICT adoption & 1,00 & 0,84 & 0,76 & 0,79 & 0,57 \\
\hline Population size & 1,00 & 0,55 & 0,69 & 0,45 & 0,42 \\
\hline Population density & 1,00 & 0,40 & 0,52 & 0,36 & 0,35 \\
\hline Population change & 1,00 & $-0,46$ & $-0,94$ & $-0,90$ & $-1,51$ \\
\hline Trade openness & 0,90 & 1,00 & 0,43 & 0,38 & 0,14 \\
\hline Employment in foreign companies & 0,84 & 1,00 & 0,28 & 0,58 & 0,30 \\
\hline Company size* & 0,81 & 1,00 & 0,83 & 0,98 & 0,96 \\
\hline High growth enterprises* & 0,86 & 1,00 & 0,69 & 0,74 & 0,73 \\
\hline Enterprise birth rates* & 1,00 & 0,73 & 0,66 & 0,62 & 0,66 \\
\hline
\end{tabular}

* Not included in the hyerarchical cluster analysis 